\title{
Immigrant integration and social investment
}

\author{
Giuliano Bonoli, University of Lausanne
}

Article published as:

Bonoli G. Immigrant integration and social investment. Journal of European Social Policy. 2020;30(5):616-627. doi:10.1177/0958928720950619

\begin{abstract}
This article offers an overview of scholarship on social investment policies in relation to the integration of immigrants and the role they can play in multicultural societies. At first sight, social investment is a promising strategy to deal with the inequalities in human capital and life chances that plague multicultural societies. However, on the basis of the available knowledge, the article shows that the benefit of social investment interventions for immigrants may be lower than expected for two main reasons. First, there are access biases in most typical social investment policies (e.g. childcare, active labour market policies, training) that tend to limit participation by non-natives. Second, employers' recruitment preferences and labour market discrimination are also likely to limit the potential of social investment interventions for immigrants. I conclude that to exploit the full potential of social investment policies in the promotion of immigrant integration, these policies need to be adapted, particularly by taking into account the essential role played by employers.
\end{abstract}

\section{Introduction}

Over the last few years, the notion of social investment has featured prominently in debates on the reform of European welfare states (Morel et al. 2012; Hemerijck 2017). Social investment refers to a range of social policies that emphasise the role of investment in human capital as a tool to fight disadvantage and to reduce inequality. Rather than compensate disadvantage through cash transfers, social investment policies aim at increasing the chances of labour market participation and accessing good quality jobs. With its focus on labour market participation, social investment de facto gives a prominent role to employers' needs and preferences.

Social investment seems a particularly promising strategy for the promotion of the integration of immigrant communities in multicultural societies. Investment in the human capital of immigrants is likely to facilitate access to the labour market given that immigrants often lack skills that are adapted to the host country's labour market (Friedberg 2000; Cheung 2013). Social investment can contribute to both the short and the long-term integration of immigrants. In the short term, training programmes and active labour market policies can help unskilled immigrants to develop the skills that are required by the labour market and as a result enter employment. In the long term, key social investment policies like childcare and support for school aged children and youth, can improve the socio-economic prospects of established immigrant communities investing in their social mobility (Brandon, 2004).

While there are reasons to believe that social investment is a promising strategy to promote the social and economic integration of immigrant and ethnic minorities (see also Burroni and Scalise; Fossati and 
Liechti, this issue), the available evidence also points to a number of potential problems. First, it has been argued that the potential impact of a social investment strategy to fight poverty and contain the rise in inequality, is limited. Social investment policies tend to benefit the middle classes and have troubles reaching the most disadvantaged (Cantillon 2011). One reason for this is the existence of access biases in many social investment policies, sometimes referred to as Matthew effects ${ }^{1}$ (Gal 1998; Bonoli et al 2017). Second, the social investment strategy assumes that once the investment in the human capital of the disadvantaged has been successfully achieved, these will find good quality jobs, adequate with regard to the skill level they have acquired. The problem is that, in a multicultural setting, at all skill levels, ethnic minorities suffer from substantial levels of labour market discrimination (Zschirnt and Ruedin 2015; Quillian et al 2017; Quillian et al 2019). Social investment policies may well succeed in improving the human capital of disadvantaged individuals and groups, but this will be of limited use if labour market discrimination prevents them from finding adequate employment. In general, discrimination by employers may concern access to jobs, but also promotions and access to quality jobs (see e.g. Moss and Tilly 2001).

Against this background, the objective of this review is to pool the available knowledge and discuss whether social investment interventions are helpful in promoting the successful social and economic integration of ethnic minorities. This review relies on a number of distinct literatures and covers the fields of social policy, migration studies, economics, and child development. These literatures are all relevant to understand the efficacy of social investment strategies, but rarely speak to one another. By pooling this knowledge, the review provides a comprehensive assessment of social investment's integration potential regarding immigrants.

Given the vastity of this research field, it has been necessary to adopt some limitations. Two are of particular importance. First the review is limited to interventions that promote labour market integration in the short or long term. Other forms of social integration measures (like measures to improve mental health conditions), which could be relevant for specific immigrant populations such as refugees, are not considered. Second, given the topic of the special issue, I focus on social investment interventions in the field of social policy. Other policy fields, such as education or integration policy, which could contain elements of social investment, are not considered here.

The paper begins with an overview of the literature on social investment, focusing on this strategy's rationale, potential and risks. It then considers current knowledge on the impact of social investment interventions on immigrant groups, in two key policy areas: childcare and ALMPs. Next, it focuses more directly on the role of employers, by considering the interaction between social investment and labour market discrimination. Then the focus shifts to what we know about ways to improve the capacity of social investment interventions to promote immigrants' labour market integration.

The paper concludes by highlighting the fact that while theoretically promising, the social investment strategy needs substantial adaptation if it is to be a successful tool for the promotion of immigrant integration.

\section{The social investment strategy}

\footnotetext{
${ }^{1}$ From St Matthews gospel, with reference to the following verse: "For unto every one that hath shall be given, and he shall have abundance: but from him that hath not shall be taken away even that which he hath"
} 
Hemerijck (2017: 19) defines social investment as "an encompassing strategy of developing, employing, and protecting human capital over the life course for the good of citizens, families, societies, and economies". The origins of the social investment strategy can be traced back to the mid1990s and early 2000s. With different terms and with different emphases, several authors have referred to a major policy shift in the discourse of international organisations such as the OECD, the World Bank but also the EU and several European countries (including the Nordic countries, Germany, the Netherlands). The "active" or "social investment" turn can be characterised as a major reorientation of social policies, emphasising human capital investment at all stages of the life course, improved access to the labour market and access to better quality employment (Bonoli 2013; Hemerijck 2012).

Some of the theoretical underpinnings of the social investment strategy are provided in the work of James Heckman who has shown in a number of evaluation studies that programmes targeted on disadvantaged children can potentially yield very high returns for society (Heckman 2006). As a result, emphasis is placed on investing in children through high quality subsidized childcare, preschool programmes and so forth (Jenson 2002; Esping-Andersen 2002; 2009). However, the social investment strategy is not limited to children. Examples of typical social investment policies include supporting disadvantaged youth in entering vocational training, and general education and other policies to help unemployed people and immigrants (re-)enter the labour market (Morel et al. 2012).

Like most influential ideas, that of social investment has attracted a reasonable amount of criticism. Hemerjick (2017) has reviewed the main critiques, including a crucial one that refers to the inability of these measures to reach the most disadvantaged in society. Several studies have shown that the key social investment polices tend to benefit the middle and upper classes more than disadvantaged people, a phenomenon usually referred to as the "Matthew effect" (Gal 1998). This bias has been found in typical social investment policies, such as subsidised childcare (Van Lancker 2013; Abrassart and Bonoli 2015; Pavolini and Van Lancker 2018), ALMPs (Heckman and Smith 2004; Bonoli and Liechti 2018) or programmes for providing vocational training to school dropouts (Pisoni 2018).

Social investment policies are intrinsically exposed to the risk of Matthew effects, for a number of reasons. First, since they imply investment in human capital, they often require some pre-existing level of skills. In order to learn professional skills, one must generally master some basic skills like literacy and numeracy. In addition, non-cognitive skills, such as perseverance or self-confidence are needed in order to successfully undergo learning processes (Heckman 2006; Esping-Andersen 2009). These skills are not evenly distributed in society and particularly immigrants may lack such qualifications for different reasons (Heath et al 2008; Pfeffer 2008).

Second, the social investment approach assumes that disadvantaged individuals and groups will be able, after public interventions, to be financially independent by participating in the labour market. The problem is that the labour market is an inherently selective institution. In order to be effective, social investment policies may need to anticipate some of the selectivity of the labour market and take employers' needs and demands into account. In social investment policies (like in other human capital formation policies) there is a trade-off between effectiveness and inclusiveness. Employers, whose role is equally essential for social investment and immigrant integration (see Introduction to this special issue), do not necessarily have an interest in inclusiveness (Bonoli and Emmenegger 2020). As a result, selectivity is likely to trickle down from employers into the whole social investment welfare state.

Third, social investment policies, like any other government policy, are subjected to political and bureaucratic logics, which can further reinforce access biases. In fact, the proponents of social investment interventions can be under political and administrative pressure to show that their policies 
are effective. The easiest way to increase success may be to restrict access to those who have a very good chance to succeed (Pisoni 2018).

\section{How do immigrants fare in the social investment welfare state?}

The literature reviewed above does not generally focus explicitly on the access biases that immigrants are likely to suffer. However, it is clear that in virtually all European countries, immigrants are overrepresented among the disadvantaged, whether in terms of access to jobs, incomes, or social integration in general (Heath and Cheung 2007; Barret and Maitre 2013). This section focuses on the issue of access biases for immigrants in three key social investment policy areas: childcare, active labour market policy, and access to jobs. These policy areas represent the different components of the social investment strategy: the focus on children and long-term investment on the one hand, and the search for more immediate gains by increasing labour market participation on the other.

\section{Childcare}

Childcare is the backbone of the social investment strategy. Investment in children increases the chances of subsequent success in school, training and ultimately in the labour market. Research on the impact of childcare and pre-school programmes on child development has shown that the return on investment can be substantial for children with a disadvantaged background (see e.g.: Barnett 1985; Heckman 2006). In addition, childcare allows (immigrant) parents to work, and as a result to increase household income and reduce welfare state dependency (Brandon 2004).

The impact of participation in formal, centre-based, childcare on child development has been investigated in several studies since the early 2000s. There seems to be a consensus that in general, participation in childcare has a positive impact on child development, but that this impact is stronger for children from disadvantaged backgrounds (Kamerman et al 2003; Magnuson et al 2007; EspingAndersen 2009: 139-140).

More recently, several new studies have exploited the gradual expansion of childcare services in Europe as a natural experiment. These studies have confirmed the view that childcare participation has a positive impact for children from disadvantaged background. A few studies have focused on Germany. For one of the German states, Lalive and Felfe (2015) find limited impact of participation in childcare overall, but a positive effect for immigrant children in terms of language and socio-emotional skills (a similar positive impact is also found for children of low educated mothers). Studying also Germany, but on the basis of a larger dataset, Cornelissen et al (2018) find the same result, i.e. a clear positive effect of participation only for disadvantaged children, including those with an immigrant background. Keiser and Bauer (2019) find that immigrant children who have experienced centre-based childcare display higher levels of overall wellbeing

The same conclusion is reached by Felfe et al (2014) for Spain, where children of socially disadvantaged parents benefit from participation, however, there is no separate analysis for children with an immigration background. For Norway, Havnes and Mogstad (2015) also find that a positive effect of participation in childcare for children living in household in the lower and middle part of the income distribution. Finally, Datta-Gupta et al (2010), using Danish data, find a positive impact of centre-based childcare on non-cognitive skills at age 7 for relative to family day care, but not relative to home care. The effects for minority children are not different. 
Unfortunately, however, in most European countries (except the Nordic countries), children growing up in disadvantaged families are less likely to be cared for in childcare centres. Several studies have identified an access bias to centre-based formal childcare. In the vast majority of European countries, the likelihood to be cared in one such centres is considerably higher for middle and upper-class children (Ghysels and Van Lancker 2011; Van Lancker and Ghysels 2012; Van Lancker 2013; Krapf 2014; Abrassart and Bonoli 2015; Pavolini and Van Lancker 2018). Most of these studies consider class or income as the determining factor of this bias, and not necessarily migrant background. In general, their results converge on the fact that the bias is general across countries, with the exception of Sweden and the other Nordic countries, where the bias is less pronounced (Van Lancker and Ghysels 2012; Krapf 2014; Sainsbury 2019). Importantly, these studies concur in showing that the bias remains after controlling for differences in parental or maternal employment.

Since some immigrant populations tend to be overrepresented among the lower social classes and income groups, it can be expected that immigrants will be hit by an access bias as well. This hypothesis is consistent with the result of the few available studies. In a study on access to childcare in a Swiss Canton, Abrassart and Bonoli (2015) found that, controlling for maternal employment and household income, the child's nationality remains a significant predictor of the probability of being in formal centre-based day care. Children from Eastern and Southern Europe are considerably less likely than Swiss and Northern European children to be in centre-based childcare. In another nationwide study Schlanser (2011) found that children born to parents stemming from Turkey or a former Yugoslavian country were less likely to be in centre-based childcare in Switzerland.

These results are consistent with the findings of Pavolini and Van Lancker (2019), who show that after controlling for maternal employment and social class, some immigrants have a lower probability of being in childcare than native children. The penalty depends on the country of origin, with children whose parents originated from India, East Asia, the middle East or Northern Africa being the least likely to be in formal childcare. However, for all immigrant groups, the probability of using childcare increases with the duration of residence in the country, suggesting that whatever factors are responsible for the penalty, these decline with time spent in the host country.

How does one explain these biases? In the literature, one finds essentially four explanations. First, the intensity of parental employment tends to be lower in lower classes and among low skilled immigrant groups. However, as already mentioned, a bias subsists after controlling for parental (in most cases maternal) employment. Second, affordability could be an obstacle for poor families. In most countries, childcare is priced according to household income, so that low-income families pay less. However, it may still be the case that in spite of a favourable fee schedule, poor families have more difficulties finding the necessary resources. The third hypothesis refers to availability. With the exception of the Nordic countries, in most European countries there is shortage of childcare provision. As a result, parents need to wait until a slot is available, but they can also try to persuade the childcare administrators to be given priority. To do this effectively requires some resources, such as knowledge of the local language and unwritten rules of behaviour, which immigrants are less likely to have. In other words, it is reasonable to assume that more resourceful parents will manage to obtain access first.

Finally, we can assume that parents have different preferences between parental, formal and informal care, and this generates the observed pattern. This explanation could help understand the underrepresentation of immigrants in centre-based childcare. Cultural preferences for maternal or 
informal care over care provided by strangers may be responsible for this effect. Pavolini and Van Lancker (2018: 887) find that, controlling for maternal employment, pro-maternal care cultural values are weakly but significantly associated with lower use of formal childcare.

Overall, the impression one gets form the literature on access biases in childcare, is that these may have different origins, but they concur in tendentially excluding less resourceful parents, particularly low skilled immigrants. This is unfortunate, because as seen above, these are the children that are most likely to benefit from being taken care of in day care centres.

\section{Active labour market policies}

Active labour market policies (ALMPs) are another important component of the social investment welfare state ${ }^{2}$. Their objective is to facilitate labour market access, including through the provision of training, job search assistance, subsidies to firms who accept to hire disadvantaged jobseekers, or temporary employment in the public of non-profit sector (Bonoli 2010; Card et al., 2017). In general, ALMPs have been shown to be effective also for immigrants, with the most effective measure for this group being job subsidies (Butscheck and Walter 2014).

From a theoretical point of view, ALMPs can generate both positive and negative access biases (Bonoli and Liechti 2018). There could be a positive access bias for (low skilled) immigrants because ALMPs are meant for individuals who have serious difficulties re-entering the labour market. As a result, we can expect a positive access bias based on entitlement criteria that result from a policy intention to reach the most disadvantaged, i.e. those who have real problems finding jobs (Heckman and Smith 2004).

However, a negative access bias for immigrants is also conceivable. Some programmes, especially the more ambitious ones, require language and other basic cognitive skills. Some immigrant groups may lack these capabilities, and will as a result be excluded from participation. In addition, immigrants' access could also be biased by the case workers' anticipation of labour market discrimination (Auer and Fossati 2019). If caseworkers know that a given jobseeker is unlikely to find a job regardless of actual skills and because of employer discrimination, they may decide not to invest in their human capital.

Finally, some measures require direct employer involvement. This is the case of job subsidies in the private sector. In this case, for the measure to be deployed, it is essential to find an employer willing to hire the jobseeker. Access to this measure could as a result be limited if employers discriminate against immigrants.

Consequently, we can build a simple model of participation of immigrants in ALMPs. ${ }^{3}$ According to this model, (low skilled) immigrants will be underrepresented in human capital-intensive programmes (e.g. vocational training) and in those that are closer to the labour market (e.g. job subsidies in the private sector). In contrast, they will be overrepresented in less ambitious and labour market distant programmes, such as temporary employment programmes in the public or non-profit sector.

While there is little dedicated research on biases in access to ALMPs, the relevant information can often be collected from standard evaluation studies. Bonoli and Liechti (2018) have done that. Using meta-analytical techniques, they examined 47 studies containing the results of 87 programme

\footnotetext{
2 This section draws on research published in Author 2019 and Author 2018

${ }^{3}$ This model is inspired by a more complex model of participation in ALMPs developed by Heckman and Smith (2004)
} 
evaluations which provided also information with regard to the eligible population and actual participants. This information allowed the researchers to identify possible biases in access.

The results show that the distribution of immigrants among ALMPs participants is indeed skewed. In short, immigrants are slightly underrepresented among participants in training programmes. They are strongly underrepresented in job subsidies for private sector employers. Finally, contrary to expectations, they are also underrepresented in temporary employment programmes.

The results of the analysis by Bonoli and Liechti (2018) are not entirely in line with the expectations based on the simple model discussed above, and point in a few different directions. First, there are very few programmes in which immigrants are overrepresented. These are found almost exclusively in the training category. Unfortunately, the literature reviewed by Bonoli and Liechti does not allow them to say anything with regard to the type of training delivered. However, it could very well be the case that migrant overrepresentation concerns only local language training. More ambitious training programmes, such as those providing full vocational training, tend to be less accessible to immigrants (see e.g. Winter-Ebmer 2006 for Austria or Lechner et al 2011 for Germany).

Second, there is a large negative access bias for immigrants in employment subsidies. This is at first sight surprising, because such subsidies are meant for disadvantaged jobseekers. It is unfortunate, because as seen above job subsides have been found to be the most promising ALMP tool for immigrants (Butschek and Walter 2014). This result may be explained by "creaming", i.e. selecting the most job-reading candidates (Koning and Heinrich 2013) or by deliberate labour market discrimination, as generally these job subsidies are provided once an employer who is willing to hire a jobseeker is found.

Finally, contrary to expectation, there is no overrepresentation of immigrants in the "temporary employment programmes" category. On the contrary, in some studies, immigrants are underrepresented in this type of programmes (see Zhang 2004 on Norway or Koch et al 2012 on Germany). This suggests that these programmes, even though designed for labour market distant candidates, are rarely meant for immigrants.

Bonoli and Liechti also report welfare regime differences in access biases. Intriguingly, nearly all the instances in which a bias is observed concern conservative and liberal welfare states. Access biases to ALMPs are rarer in the Nordic countries, particularly for training measures (Bonoli and Liechti 2018: 905). Future research should find out why the Nordic countries are more successful in limiting the access bias to ALPMs and training.

These results suggest that access biases may constitute serious problems with regard to the ability of ALMPs to support disadvantaged immigrants. The main reason for this may not be so much the lack of pre-existing human capital, as hypothesised, but more employers' discrimination of such candidates and absence of suitable programmes.

\section{Access to jobs}

The promise of the social investment strategy depends crucially on the ability of the target groups of social policy to profit from human capital investment and integrate the labour market. While this promise may be credible in general terms, when it comes to immigrants it is problematic as immigrants and ethnic minorities face relatively high levels of discrimination in the labour market (see e.g.; Ruedin and Zschirnt 2016; Bertrand and Duflo 2017; Quillian et al 2017; Quillian et al 2019). 
In this respect it is striking that the literature on social investment has not focused more on employer preferences and particularly on discrimination. Potentially, labour market discrimination could undo much of the effect of social investment policies. This comes out clearly by comparing the average effect size of ALMPs to the impact of discrimination. With regard to ALMPs, a meta-analysis of 15 impact studies found that participation increases the hazard rate of finding a job by $9 \%$ on average (Filges et al 2015: 39). Meta-analyses of studies of discrimination typically find that all else equal, applicants from ethnic groups that are exposed to discrimination have a 30-50\% lower probability to be invited for a job interview (Zschirnt and Ruedin 2016; Quillian et al 2017; Quillian et al 2019). Thus, effect sizes of ALMPs and discrimination are clearly within the same range, with, if anything, discrimination having a larger impact.

A credible social investment strategy should therefore include an anti-discrimination component. However, fighting labour market discrimination is difficult. Decades of anti-discrimination legislation and policy in the US have not managed to reduce discrimination against blacks (Quillian et al. 2017). In Europe, discrimination levels against immigrants form culturally distant countries have remained roughly constant across countries for decades (Zschirnt and Ruedin 2017; Quillian et al 2019). Attempts at fighting discrimination by intervening in the recruitment process, for example by applying blind hiring strategies (i.e. anonymous CVs) or by trying to reduce employers' biases, have produced inconsistent results (Bertrand and Duflo 2017; Krause et al 2012; Behagel et al 2014).

Employers hiring preferences and practices are likely to constitute a serious limitation on the impact that the social investment strategy can have on the integration of immigrants. While there are no easy solutions to this problem, the reality of how labour markets work should be more explicitly incorporated in the definition of a social investment strategy.

Table 1: Summary of main results of studies on migration and social investment

\begin{tabular}{|l|l|l|}
\hline Policy sub-field & Main results & Key references \\
\hline Childcare & $\begin{array}{l}\text { Children with low skilled } \\
\text { parents and an immigrant } \\
\text { background are less likely } \\
\text { to be in centre-based } \\
\text { childcare. }\end{array}$ & $\begin{array}{l}\text { Abrassart and Bonoli 2015; Lalive and } \\
\text { Felfe 2015; Pavolini and Van Lancker } \\
\text { 2018; Schlanser 2011; Van Lancker } \\
\text { 2013; Van Lancker and Ghysels 2012. }\end{array}$ \\
\hline ALMPs & $\begin{array}{l}\text { Immigrants (or in the US, } \\
\text { ethnic minorities) are less } \\
\text { likely to participate in } \\
\text { ALMPs. }\end{array}$ & $\begin{array}{l}\text { Auer and Fossati 2019; Bonoli and } \\
\text { Liechti, 2018 (Meta-analysis); Heckman } \\
\text { and Smith 2004 }\end{array}$ \\
& $\begin{array}{l}\text { Effect is strongest for } \\
\text { employment subsidies; } \\
\text { average for temporary } \\
\text { employment programmes } \\
\text { and weaker for training }\end{array}$ & \\
\hline $\begin{array}{l}\text { Access to the labour } \\
\text { market }\end{array}$ & $\begin{array}{l}\text { Immigrants from culturally } \\
\text { distant countries are less } \\
\text { likely to be invited to job } \\
\text { interviews in all countries } \\
\text { for which studies are } \\
\text { available. }\end{array}$ & Ruedin and Zschirnt 2016; Quillian et al \\
2017; Quillian et al 2019 (all meta- \\
analyses)
\end{tabular}




\section{Can the social investment state be made more immigrant friendly?}

The literature reviewed above suggests that while theoretically promising, a standard social investment approach may fail to integrate individuals with an immigrant background. However, some of the problems discussed above can be addressed with adequate policy design (Hemerijcjk 2017). While dedicated research on how the design of social investment interventions can reduce access biases and employers' discrimination is still missing, the available evidence points us in a few promising directions.

Conditionality. In social policy the notion of conditionality refers to behaviours that must be adopted in order to receive full benefits, most typically, job search efforts. However, conditionality can also be used to promote the use of given services. The prime example are "Conditional cash transfer programmes" (CCTs). These exist mostly in emerging countries and combine a cash benefit for families with particular obligations such as school attendance or medical check-ups for children. Overall, CCTs are considered an effective way to help hard to reach populations (Baird et al 2013; Garcia and Saavedra 2017). The logic of CCTs has been applied also in Europe, but mostly to niche programmes such as cash incentives for pregnant mothers to encourage health check-ups. The logic could be extended to other programmes, but would be appropriate only if the cause of underutilization is lack of demand (Kis et al 2014). As seen above, both in relation to childcare and ALMPs, lack of demand does not seem to be a problem. Instead, insufficient and/or inadequate supply is the most likely culprit. Conditionality may play a role in improving immigrant's access to specific services, but is unlikely on its own to solve the access bias problem identified above.

Increasing supply. If the main obstacle to immigrant participation in relevant programmes is lack of supply, then the obvious solution is to increase it. This may reduce the Matthew effects observed in childcare. The work by Van Lancker and colleagues suggest that lack of availability is indeed a major factor explaining the bias in access to childcare. In their comparison of Sweden and Flanders, two territories that have a similar childcare policy, Van Lancker and Ghysel (2012) find that children form a disadvantaged background are much more likely to attend in Sweden. They explain this result with reference to higher levels of availability. This finding is confirmed in a more extended study of EU 27 countries, showing again that higher levels of supply are associated with a less pronounced bias (Van Lancker 2013). These results are intuitive. If childcare is a scarce resource, access to it will be difficult for disadvantaged groups. These studies do not specifically consider immigrant children. However, since migration background has been found to limit access to childcare services, we can assume similar mechanisms to be at play for immigrant children.

Increasing supply and guaranteeing universal access to services is probably one of the safest ways to minimise the type of access biases that penalise individuals and families with an immigration background. This has been convincingly shown in relation to childcare and there is reason to believe that it would apply to ALMPs and possibly other social investment interventions. Given that, as seen above, Matthew effects in ALMPs seem to be rarer in the Nordic countries, where this policy is most developed, supports this interpretation.

Interventions outside the realm of social policy. Some of the issues discussed above cannot be addressed only with social policy interventions. Social investment strategies that improve immigrant 
integration should include interventions in labour law, equal opportunity policy, and antidiscrimination policy. Otherwise, as argued above, the risk is the investments made will pay off in a limited way only.

\section{Conclusion}

It is generally assumed that social investment is a suitable strategy to deal with the challenge represented by immigrant integration in multicultural societies. This thematic review has shown that this view is not entirely consistent with what we know from empirical studies of policy and on the labour market integration of immigrants.

First, social investment policies in most countries do not seem to reach the most disadvantaged populations and immigrants in particular. This is the case both with childcare and ALMPs. An exception seems to be the Nordic countries, particularly Sweden, where access biases to key social investment policies are less pronounced. These countries seem to be doing slightly better than other countries in terms of guaranteeing access to key social investment policies.

Second, the literature on labour market discrimination reviewed in this article suggests that when it comes to immigrant integration, access biases and the Matthew effect are not the only obstacles to an effective social investment strategy. Employer discrimination, in fact, could be undermining much of the potential benefits of social investment. Social investment policies do not contain an antidiscrimination component, and simply assume that better human capital will be conducive to better access to jobs. Unfortunately, this assumption is not valid for many immigrant groups.

These observations have implications for research and for policy. With regard to research, we need to understand better what causes access biases and how to overcome them. In addition, we need research that connects social investment interventions and employers' recruitment decisions (see Fossati and Liechti, this issue). For example, how do social investment interventions impact on employers' perceptions of minority applicants? Can discrimination be reduced by involving employers in the design and implementation of social investment policies (Burroni and Scalise, this issue)?

Social investment interventions remain an attractive strategy to promote immigrant integration and successfully manage multicultural societies. However, in order to fully exploit the potential of these interventions, policy adaptation is needed. Increasing supply of the relevant services seems to be one of the most promising strategies. In addition, employer discrimination should be addressed more directly and forcefully. Both research and policy should give more consideration to the role of employers in the deployment of a successful social investment strategy. 


\section{Literature}

Abrassart, A., \& Bonoli, G. (2015). Availability, cost or culture? Obstacles to Childcare Services for Low Income Families. Journal of social policy 44(4), 787-806.

Auer, D., \& Fossati, F. (2019). Compensation or Competition: Immigrants' Access Bias to Active Labour Market Measures. Social policy and Administration, forthcoming.

Baird, S., Ferreira, F. H. G., Özler, B., \& Woolcock, M. (2013). Relative effectiveness of conditional and unconditional cash transfers for schooling outcomes in developing countries: A systematic review: Campbell Systematic Reviews 2013: 8.

Barnett, W. S. (1998). Long-term cognitive and academic effects of early childhood education on children in poverty. Preventive Medicine, 27(2), 204-207.

Barrett, A., \& Maitre, B. (2013). Immigrant welfare receipt across Europe. International Journal of Manpower, 34(1), 8-23.

Behaghel, L., Crépon, B., \& Barbanchon, T. L. (2014). Unintended effects of anonymous resumes. Bonn: IZA, DP No. 8517.

Bertrand, M., \& Duflo, E. (2017). Field Experiments on Discrimination. In A. V. Banerjee \& E. Duflo (Eds.), Handbook of Economic Field Experiments (pp. 309-393). Amsterdam: North Holland.

Bonoli, G. (2013). The origins of active social policy. Active labour market policy and childcare in a comparative perspective. Oxford: Oxford University Press.

Bonoli, G., Cantillon, B., \& van Lancker, W. (2017). Social investment and the Matthew effect. In A. Hemerijck (Ed.), The uses of social investment. Oxford: Oxford University press.

Bonoli, G., \& Emmenegger, P. (2020). The Limits of Decentralised Cooperation. The Promotion of Inclusiveness in Collective Skill Formation Systems. Journal of European Public Policy, forthcoming. doi: https://doi.org/10.1080/13501763.2020.1716831

Bonoli, G., \& Liechti, F. (2018). Good intentions and Matthew effects: access biases in participation in active labour market policies. Journal of European Public Policy 25(6), 894-911. doi:

Brandon, P. (2004). The Child Care Arrangements of Preschool-Age Children in Immigrant Families in the United States. International Migration, 42(1), 65-87.

Bredgaard, T., \& Halkjær, J. L. (2016). Employers and the Implementation of Active Labor Market Policies. Nordic journal of working life studies, 6(1), 47-59.

Busemeyer, M., \& Trampusch, C. (Eds.). (2012). The political economy of collective skill formation. Oxford: Oxford University Press.

Butschek, S., \& Walter, T. (2014). What active labour market programmes work for immigrants in Europe? A meta-analysis of the evaluation literature. IZA Journal of Migration, 3(1).

Cantillon, B. (2011). The paradox of the social investment state: growth, employment and poverty in the Lisbon era. Journal of European Social Policy, 21(5), 432-449. doi: $10.1177 / 0958928711418856$

Card, D., Kluve, J., \& Weber, A. (2017). What works? A meta analysis of recent active labor market program evaluations. Journal of the European Economic Association, 16(3), 894-931.

Cheung, S. Y. (2013). Ethno-religious minorities and labour market integration: generational advancement or decline? Ethnic and Racial Studies, 37(1), 140-160.

Cornelissen, T., Dustmann, C., Raute, A., \& Schonberg, U. (2018). Who Benefits from Universal Child Care? Estimating Marginal Returns to Early Child Care Attendance. Journal of Political Economy, 126(6), 2356-2409. doi: 10.1086/699979

Datta-Gupta, N., \& Simonsen, M. (2010). Non-cognitive child outcomes and universal high-quality child care. Journal of Public Economics, 94(1-2), 30-43.

Esping-Andersen, G. (2009). The incomplete revolution. Adapting to women's new roles. Cambridge: Polity Press.

Esping-Andersen, G. (Ed.). (2002). Why We Need a New Welfare State. Oxford: Oxford University Press. 
Felfe, C., \& Lalive, R. (2018). Does early child care affect children's development? Journal of Public Economics, 159, 33-53.

Felfe, C., Nollenberger, N., \& Rodríguez-Planas, N. (2015). Can't buy mommy's love? Universal childcare and children's long-term cognitive development. Journal of Population Economics, 28, 393-422.

Filges, T., Smedslund, G., Knudsen, A.-S. D., \& Jørgensen, A.-M. K. (2015). Active Labour Market Programme Participation for Unemployment Insurance Recipients: A Systematic Review. Campbell Systematic Reviews, 2015/2.

Friedberg, R. M. (2000). You Can't Take It with You? Immigrant Assimilation and the Portability of Human Capital. Journal of Labor Economics, 18(2), 221-251.

Gal, J. (1998). Formulating the Matthew Principle: on the role of the middle classes in the welfare state. Scandinavian Journal of Social Welfare, 7(1), 42-55.

Garcia, S., \& Saavedra, J. Educational impacts and cost-effectiveness of conditional cash transfer programmes in developing countries: a meta-analysis. Cambridge, MA: NBER Working Paper 23594.

Ghysels, J., \& Van Lancker, W. (2011). The unequal benefits of activation: an analysis of the social distribution of family policy among families with young children. Journal of European Social Policy, 21(5), 472-485. doi: 10.1177/0958928711418853

Havnes, T., \& Mogstad, M. (2015). Is universal child care leveling the playing field? Journal of Public Economics, 127, 100-114. doi: 10.1016/j.jpubeco.2014.04.007

Heath, A., \& Cheung, S. Y. (2007). The comparative study of ethnic minority disadvantage in western labour markets In A. Heath \& S. Y. Cheung (Eds.), Unequal Chances: Ethnic Minorities in Western Labour Markets (pp. 1-44). Oxford: Oxford University Press.

Heath AF, Rothon C and Kilpi E. (2008) The second generation in Western Europe: Education, unemployment, and occupational attainment. Annual Review of Sociology 34: 211-235.

Heckman, J. J. (2006). Skill Formation and the Economics of Investing in Disadvantaged Children Science(312), 1900-1902.

Heckman, J. J., \& Smith, J. A. (2004). The determinants of participation in a social program: Evidence from a prototypical job training program. Journal of Labor Economics, 22(2), 243-298. doi: $10.1086 / 381250$

Hemerijck, A. (2012). Changing welfare states. Oxford: Oxford University Press.

Hemerijck, A. (2017). Social investment and its critics. In A. Hemerijck (Ed.), The uses of social investment. Oxford: Oxford University Press.

Jenson, J. (2002). From Ford to Lego : redesigning welfare regimes. Boston: Annual Meeting of the American Political Science Association.

Kamerman, S., Neuman, M., Waldfogel, J., \& Brooks-Gunn, J. (2003). Social policies, family types and child outcomes in selected OECD countries. Paris: OECD Social, employment and migration working papers No. 6.

Kis, A. B., Holle, A., Medgyesi, M., Mosuela, C., O’Crosby-Nagy, M., \& Temesváry, Z. (2014). Study on Conditional cash transfers and their impact on children. Brussles: European Commission.

Koch, S., and Fertig, M. (2012) Evaluation von Arbeitsgelegenheiten in der Mehraufwandsvariante im Jobcenter München. IAB Forschungsbericht 1: 1-70.

Krapf, S. (2014). Who uses public childcare for 2-year-old children? Coherent family policies and usage patterns in Sweden, Finland and Western Germany. International Journal of Social Welfare, 23(1), 25-40. doi: 10.1111/ijsw.12031

Krause, A., Rinne, U., \& Zimmermann, K. (2012). Anonymous job applications in Europe. IZA Journal of European Labor Studies, 1(5).

Lechner, M., Miquel, R, and Wunsch, C. (2011). "Long-Run Effects of Public Sector Sponsored Training in West Germany." Journal of the European Economic Association 9 (4): 742-84.

Magnuson, K. A., Ruhm, C., \& Waldfogel, J. (2007). Does prekindergarten improve school preparation and performance? Economics of Education Review, 26(1), 33-51. doi:

10.1016/j.econedurev.2005.09.008. 
Morel, N., Palier, B., \& Palme, J. (Eds.). (2012). Towards a Social Investment Welfare State?: Ideas, Policies and Challenges. Bristol: The Policy Press.

Moss, P., \& Tilly, C. (2001). Stories employers tell: race, skill, and hiring in America. New York: Russel Sage Foundation.

Pavolini, E., \& Van Lancker, W. (2018). The Matthew effect in childcare use: a matter of policies or preferences? Journal of European Public Policy, 25(6), 878-893. doi: 10.1080/13501763.2017.1401108

Pavolini, E., \& Van Lancker, W. (2019). The immigrant penalty in childcare use: an empirical exploration for 22 European countries: unpublished paper.

Pfeffer FT. (2008) Persistent Inequality in Educational Attainment and its Institutional Context. European Sociological Review 24: 543-565.

Pisoni, D. (2018). Activating the most disadvantaged youth in Switzerland: Administratively too risky, politically too costly? International Social Security Review, 71(4), 51-70.

Quillian, L., Pager, D., Hexel, O., \& Midtboen, A. H. (2017). Meta-analysis of field experiments shows no change in racial discrimination in hiring over time. Proceedings of the National Academy of Sciences of the United States of America, 114(41), 10870-10875.

Quillian, L., Heath, A., Pager, D., Midtbøen, A., Fleischmann, F., \& Hexela, O. (2019). Do Some Countries Discriminate More than Others? Evidence from 97 Field Experiments of Racial Discrimination in Hiring. Sociological Science, 6, 467-496.

Sainsbury, D. (2019). Policy constructions, immigrants' social rights and gender: The case of Swedish childcare policies. Journal of European Social Policy, 29(2), 213-227. doi: $10.1177 / 0958928718762311$

Van Lancker, W. (2013). Putting the child-centered strategy to the test: Evidence for the EU 27. European Journal of Social Security, 15(1), 4-27.

Van Lancker, W., \& Ghysels, J. (2012). Who benefits? The social distribution of subsidized childcare in Sweden and Flanders. Acta Sociologica, 55(2), 125-142. doi: 10.1177/0001699311433428

Winter-Ebmer, R. 2006. "Coping with a Structural Crisis: Evaluating an Innovative RedundancyRetraining Project." International Journal of Manpower 27 (8): 700-721. Zhang, T. (2003). Identifying treatment effects of active labour market programmes for Norwegian adults: University of Oslo, Department of Economics, Memorandum 26.

Zschirnt, E., \& Ruedin, D. (2016). Ethnic discrimination in hiring decisions: A meta-analysis of correspondence tests 1990-2015. Journal of Ethnic and Migration Studies, 42(7), 1-19. 